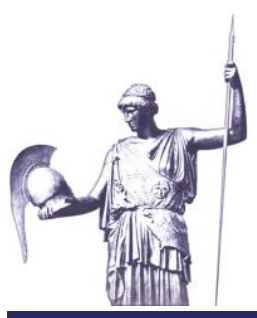

Connections: The Quarterly Journal

ISSN 1812-1101, e-ISSN 1812-2973

Джеймс Хаукрофт, Connections QJ 17, № 2 (2018): 87-92

https://doi.org/10.11610/Connections.rus.17.2.06

Взгляд практика

\title{
Будущее терроризма: взгляд практика
}

\section{Джеймс Хаукрофт}

Европейский Центр исследований по вопросам безопасности им. Джорджа К. Маршалла, https://www.marshallcenter.org

Резюме: В этом эссе автор - опытный офицер разведки и в настоящее время руководитель программы по контртерроризму Европейского центра исследований по вопросам безопасности им. Джорджа К. Маршалла - дает обзор будущего развития международного терроризма в трех главных аспектах: мотивы; тактика, оружие и технологии; и мишени.

Ключевые слова: терроризм, контртерроризм, война с терроризмом.

Комиссия 9/11 указала на "отсутствие воображения» в среде контртеррористического сообщества в качестве ключевой причины неспособности остановить нападение на Всемирный торговый центр и Пентагон в 2001 году. Неспособность представить себе, что сами самолеты могут быть использованы в качестве оружия, способствовало тому, что заговор не был раскрыт и не были предприняты соответствующие меры. Поэтому для профессионалов по контртерроризму важно уметь думать с точки зрения террористов и учитывать возможные способы, которыми они будут приспосабливаться и применять новые подходы в будущем.

Программа исследований по вопросам терроризма и безопасности (ПИТБ) Европейского центра исследований по вопросам безопасности им. Джорджа К. Маршалла в Гармиш-Партенкирхене сводит воедино на месяц дважды в год профессионалов и практиков контртерроризма со всего мира для изучения современного терроризма, инструментов и стратегий, которые необходимы для борьбы с ним. 68 участникам из 48 стран, которые принимали участие в ПИТБ в июле 2018 , была поставлена задача использо- 
вать свое информированное воображение и обдумать возможные пути развития терроризма в следующие десять лет. Участников попросили дать свои оценки в трех основных областях: мотивы; тактика, оружие, технологии; вероятные мишени.

\section{Мотивы}

Группа пришла к заключению, что в ближайшем будущем главную роль в мотивации глобальных террористов продолжит играть салафистско-джихадистская идеология. Увеличивающееся молодое население с ограниченными экономическими и социальными возможностями, подвергающееся опосредствовано волнениям и приключениям через современные социальные медиа, будет поддаваться этим продаваемым в разнос приключениям и стремлениям из реальной жизни через участие в террористических организациях, - как это успешно делало ИГИС в последние годы. Поэтому растущее экономическое неравенство в сочетании с разочарованием, порожденным ограниченными возможностями для занятости увеличивающегося молодого населения, было отмечено как постоянная движущая сила джихадистского терроризма, но также и для потенциального возрождения левацкого политически обусловленного насилия.

Когда большие массы населения пересекают границы либо из-за вооруженных действий, либо из-за климатических проблем или из-за отсутствия экономических возможностей, вероятным является разрастание радикальных, анти-иммигрантских и анти-интеграционных фракций, созданных для «защиты» идентичности коренной нации против чужой культуры и религии. Так же вероятным будет формирование реципрокных групп «самозащиты» в общностях иммигрантов, которые готовы использовать насилие для достижения политического влияния в целях защиты своей группы против воспринимаемой маргинализации. Существующие террористические организации, возможно, будут вербовать сторонников в среде уязвимых и маргинализованных иммигрантских общностях, позиционируя себя в качестве их защитников против враждебного или безразличного населения принимающей нации.

И наконец, проблемой может стать негативная реакция на использование передовых технологий, которые заменят неквалифицированную рабочую силу. Экономическое неравенство и потеря рабочих мест, порожденные современными технологиями, окажется проблемой для государств, с которой они будут справляться трудно, что будет приводить к обидам, которые можно эксплуатировать в неблаговидных целях. При таком сценарии, перспектива появления "технофобского» терроризма не является нереалистической. 


\section{Тактика, оружие и технологии}

Участники ПИТБ отметили, что наиболее распространенными видами оружия сегодня являются огнестрельное оружие и взрывные устройства. Мало кто ожидает, что это изменится в течение следующих десяти лет. Огнестрельное оружие и мины оказались эффективными, и их сравнительно легко приобрести и использовать. Тогда как властями было израсходовано большое количество ресурсов для борьбы с угрозами для гражданской авиации, террористы широко использовали обыкновенные легковые машины и грузовики для осуществления нападений во множестве мест, в том числе в Барселоне, Берлине, Лондоне, Стокгольме и Нью-Йорк сити. Из-за относительно простого осуществления этих терактов и их успешности в последнее время, не следует ожидать отказа от этой конкретной тактики. Технологические приложения, направленные на расширения использования беспилотных легковых машин и грузовиков, являются благом для общества, но также вызовом, требующим их защиты для предотвращения их использования для осуществления дистанционных нападений против гражданских или государственных целей.

Террористы уже начали использовать беспилотные летательные аппараты, иногда в составе стай, как это имело место в предыдущем году как в Сирии, так и в Ираке. Распространение имеющихся в продаже еще более многофункциональных беспилотных летательных аппаратов и расширение их роли в бизнесе и в секторе доставки неминуемо приведет к их более частому использованию террористами. Использование беспилотных летательных аппаратов в попытке покушения на президента Венесуэлы Мадуро 4 августа 2018 года является одним из первых примеров все большей угрозы, в которую превратятся беспилотные летательные аппараты в будущем. Неизбежный прогресс в миниатюризации и программировании беспилотных аппаратов породит множество проблем для служб безопасности, которые уже пытаются приспособиться к быстрой эволюции технологии беспилотных устройств.

Потенциальное использование оружия массового уничтожения (ОМУ), хотя все еще является маловероятным, остается тактикой, имеющей потенциал для осуществления непропорционального воздействия и влияния на гражданское население. Усиление урбанизации и постоянно растущая плотность населения будут мультиплицировать и расширять эффект ОМУ, каким бы оно не было - химическим, биологическим или радиационным. Мгновенное и не цензурированное общение в социальных сетях спровоцирует панику среди населения, и возможно помешает попыткам официальных властей предоставлять точную и адекватную информацию о настоящем характере и степени угрозы для гражданского населения.

Среди практиков борьбы с терроризмом уже существует понимание, что происходит конвергенция между действиями и деятельностями структурами организованной преступности и террористами. Это не является чем-то 
неожиданным, новым или пагубным, и в некоторых случаях открывает возможности для ее использования представителями органов безопасности. Участники отметили, что связь между террором и преступностью, скорее всего, будет расширяться и углубляться, усложняя работу государственных ведомств, занимающихся этой сетевой угрозой.

Кибер пространство все чаще используется преступниками и финансовыми вымогателями, и оправданно было бы ожидать, что террористы, учась и используя ноу-хау своих уголовных собратьев, начнут использовать эту методологию и угрожать государствам с тем, чтобы они выполняли их политические требования. Очевидно, террористы с кибер-умениями во все большей степени будут использовать уязвимости по мере того, как государства и повседневные потребители во все большей степени будут полагаться на интернет. Заглядывая в будущее, можно ожидать, что быстро развивающийся «Интернет вещей», который используется для управления устройствами и приложениями, занимающими центральное место в повседневной жизни, будет подвергаться срывам, манипуляциям и принуждению. Имея в виду кибер-операции, стоило бы обратить внимание на факт, что в большинстве нынешних определений или представлений о терроризме содержится элемент насилия или угроза насилием. Возможно, это понимание следует расширить с тем, чтобы оно включало действия, которые угрожают безопасности и благополучию населения. Примерами таких действий могут быть угрозы нападением или действительные нападения на системы водоснабжения или электроснабжения, систем банков или на сети управления воздушным движением, которые не обязательно приводят к физическим разрушениям.

\section{Мишени}

Участники ПИТБ отметили, что одной из мишеней, вероятно, останутся транспортные сети, которые трудно защитить, и на которых нападению может подвергнуться большое число гражданских лиц. Хотя в прошлом нападениям подвергались авиалинии и поезда, паромы и круизные корабли специально были идентифицированы как транспортные варианты, которые, по-видимому, в глазах террористов имеют ряд преимуществ в качестве мишеней. Привлекательными для террористов останутся и такие «мягкие» цели, как уличные фестивали, спортивные события и музыкальные площадки. Туристические объекты, которые привлекают большое число международных посетителей, трудно защитить способами, которые не мешали бы туристам. Для террористов нападение на такой объект обеспечивает широкомасштабную всемирную известность. При терактах в 2015 году в Музее Бардо и на пляже Сусс в Тунисе погибли граждане четырнадцати государств Европы, Азии и Южной Америки. Такие нападения, конечно, приводят к существенному экономическому ущербу для стран, в которых они совершаются. 
Участники также отметили, что все более вероятными станут нападения, осуществляемые детьми и нападения на детей. Индонезия стала свидетелем нападений, осуществленных семьями с детьми в мае 2018, а в августе теракты были осуществлены детьми в Чечне. Когда в разные страны стали возвращаться их граждане, которые присоединились к Аль-Каиде и ИГИС в Сирии и Ираке, эти государства начали пытаться определить и применить самые подходящие способы и методы для разрешения проблемы детей, так называемых «детенышей халифата». Террористические нападения, затрагивающие детей либо в качестве нападающих, либо в качестве жертв, вызывают сильные эмоции. Ни одна часть людей разных сообществ не является более ценной, чем дети. Нападения на школы, в общем случае, имеют большое воздействие и не создают больших рисков для нападающих. Все ожидают, что школы являются безопасным местом для детей. Нападения на школы разрушают эту уверенность, получают огромную известность и порождают сильные эмоции.

Власти под огромным давлением эмоциональной публики будут вынуждены предпринимать крайние и публичные меры для демонстрации своей способности защитить наиболее уязвимую часть общества. Крайняя, эмоциональная реакция со стороны сил безопасности неизбежно приведет к скоропалительным, плохо подготовленным и контрпродуктивным мерам. Жестокие школьные нападения хотя и создают широкую известность и вызывают страх, содержат для нападающих риск гальванизирования общественной поддержки борьбы с террористической группой, как было в случае резни в школе Техрик-и-Талибан в Пешаваре, Пакистан, в 2014 году.

Если для терроризма в будущем все более определяющими мотивами будут увеличивающееся неравенство и экономические проблемы, вероятными мишенями для террористов станут штаб-квартиры и другие физические и человеческие активы больших мульти-национальных корпораций. Нападения могут совершаться против инфраструктуры и личного состав в странах, где нет больших возможностей обеспечивать безопасность, но они будут иметь глобальное воздействие из-за множества международных связей подвергающейся нападению корпорации. Теракты против безликих мульти-национальных корпораций, которыми владеют и которыми управляют обычно иностранцы, в качестве удара против неравенства, от которого страдает население, могут быть привлекательным террористическим нарративом, привлекающим симпатию и поддержку их действий. Подобным образом компании, которые специализируются на технологиях и автоматизации, вероятно, окажутся привлекательными мишенями для «технофобов». Правительства будут подвергаться большому давлению, оправдывая расходование скудных ресурсов для защиты богатых корпораций, а не своих собственных граждан, что означает, что этим мульти-национальным корпорациям придется рассчитывать, в основном, на себя для предупреждения, защиты и применения сдерживающих мер, что приведет к дальнейшей приватизации в сфере контртерроризма. 
Мотивы, тактика и цели, идентифицированные и обсужденные участниками ПИТБ не являются никоим образом исчерпывающими, но они результат неофициального консенсуса, достигнутого в глобальной команде опытных практиков контртерроризма. Идентифицированные возможности требуют не фантастического технологического прогресса, это адаптации инструментов, средств и приложений, которые недороги и широко доступны для обыкновенных людей сегодня и к которым террористы уже проявляли интерес. Также, вероятные будущие поводы для обид, которые участники идентифицировали, уже присутствуют на первых страницах газет по всему миру. Когда поводы для обид и возможные оружия идентифицированы, вычисление потенциальных мишеней определенно возможно, если аналитики и практики рассмотрят угрозу с точки зрения террористов. Это позволит руководителям государств принимать информированные решения касательно распределения ограниченных ресурсов способом, который наиболее эффективен для защиты граждан и их образа жизни.

\section{6 авторе}

Джеймс Хаукрофт является директором Программы исследований по вопросам терроризма и безопасности Центра им. Джорджа К. Маршалла. Профессор Хаукрофт вышел в отставку в звании полковника после 30 лет работы в качестве офицера разведки в Корпусе морской пехоты Соединенных Штатов. Он служил на многих тактических и оперативных разведывательных должностях в Корпусе морской пехоты, от уровня пехотного батальона и до уровня экспедиционной группы морской пехоты. В число его боевых командировок входят служба во 2-й дивизии морской пехоты в операции «Пустынная буря» и работа на должности помощника начальника штаба по разведке (G2) в 1-й дивизии Морской пехоты и 1-й экспедиционной группы морской пехоты в Ираке. E-mail: james.howcroft@marshallcenter.org. 